\title{
IMPROVING STUDENTS' READING COMPREHENSION THROUGH PICTURE AND PICTURE
}

\author{
Hapsari Ovina Mantiri, Noldy Pelenkahu, and I. Javier C. Tuerah \\ English Education Department \\ Faculty of Language and Arts \\ Universitas Negeri Manado \\ Tondano, Indonesia \\ mantirihapsari@gmail.com
}

\begin{abstract}
The purpose of the study is to improve students' reading comprehension of narrative text using Picture and Picture. This study is delimited on using picture and picture in teaching reading comprehension in Narrative Text to the first year student of SMK Santa Familia Tomohon. In this research, the researchers use quantitative research. Where quantitative research is used to obtain and to collect the data in the form of numbers, through Pre-experimental design with one group pre-test and post-test. Based on the explanation of previous chapters, it can be concluded that; picture and picture technique is effective to improve students' reading comprehension, teaching reading comprehension by using picture and picture can help student improving their comprehension in reading and increase their cooperation to develop the other language skills. Then, the result of this research shows that the students' score in Post-test is higher than their score in Pre-test. It means that Picture and Picture technique in teaching reading comprehension is effective. Therefore, it is suggested to apply Picture and picture technique in class related to the situation and material that is going to be taught in school to improve more about students' skill not only in group but also personally. The teacher is suggested to pay more attention to increase students' comprehension in reading.
\end{abstract}

Keywords: Reading, Picture and Picture Technique, Pre-experimental

\section{INTRODUCTION}

English has an important role. It is because English is an international language that has to be mastered by the people. In Indonesia, English is the first foreign language that should be taught in school. Liando (2012) says "Indonesia has adopted English as a tool of communication to establish relationship with other countries". Also from Lado (1961: 2) "English language is one of the international languages which are used for communication among countries in the world".
So, English helps us for communicating with our friends. Also, English helps us in learning process and getting information, knowledge from many sources such as magazine, blog, internet, newspaper, or books only by reading. For beginners who learn English as a foreign language comprehension of a text is not as easy as that of fluent readers English has been taught in Indonesia schools for several decades (Maru, 2009). As known that English is the first foreign language that should be taught in school. 
So, from the four language skills (listening, speaking, reading and writing), reading is very influential. As stated by Maru (2009) "Teaching language is not merely a matter of techniques and teachers' teaching role as well as material but also aspect related to an atmosphere or climate within the teaching and learning take place"(p.2).

Why reading is very influential? In classroom, the reading activity refers to the activity of transferring information from the writer to the reader. According to Livianni Lambe (2011), reading is an activity and process that is done by reader to understand written texts.

So, reading cannot be separated from comprehension as stated by Smith and Robinson (1980:205) "Reading means understanding, evaluating, and utilizing of information and ideas gained through the interaction between the reader and the writer".

Also after the readers or students read a text, they have to understand about what the writer means. We all know that when the students are going to read an English text, they would face so many problems in reading activities such as analysing the text, finding the topic or the main idea of the text, answering the questions and also describing the text. So, the teacher needs to give more attention about the students' interest on reading English text.

There are so many ways for getting student attention to learn English. As the facilitator, it is a must for the teacher to make sure that the student interest in learning English.

English as a subject has been introduced in Indonesia from Indonesia as a foreign language has been focused on developing the four language skills reading, writing, speaking, and listening-with various degree of proficiency (Lambe, 2017).
Therefore, a way to get students interest in English especially in reading is teaching them an easy way which is innovative for example using picture. So based on the explanation, the writers choose "Picture and Picture Technique" to help the students to improve and encourage their reading comprehension.

Here are the several definitions of terms that used in this research:

- Teaching is showing or helping someone how to do seomthing providing knowledge causing to know or to understand (Brown 1980:7).

- Reading is the act, pratice or art in any sense of verb; a public recital; the act of reading formally to a legislative body of a bill, etc; mater which is read or is designed to be read (The International Webster Comprehensive Dictionary of The English Language 1996: 1049)

- Reading Comprehension is a through process which readers become aware and understand it, in term of experimental background and intrepret it in relation to their own purposes (Kennedy 1981).

- Picture and Picture itself, focus on the picture that sorted by the students into alogic sequences, also it helps students to develop their interactions from each other in classroom.

\section{RESEARCH METHODOLOGY}

\subsection{Research Design}

In this research, the researchers use quantitative research. Where quantitative 
research refers to obtain and to collect the data in the form of numbers through Preexperimental design with one group pre-test and post-test. The pre-test is the test which given to the students' right before the treatment. Then, the posttest is the test which given to the students right after the treatment, to see and to find out the students' achievement.

Butler $\quad(1985 ; 65) \quad$ states "Experimental studies are those in which the investigator deliberately manipulate some factors or circumstances in order to test the effect of some other phenomenon".

So, there are two tests that the researchers give to the student. T1 as Pre-test and T2 as Post-test with $\mathrm{X}$ symbolizes the treatment that the researchers give before $\mathrm{T} 2$ or Post-test. It can be understand by the design bellow:

\begin{tabular}{|c|c|c|}
\hline Pre-Test & Treatment & Post-Test \\
\hline T1 & $\mathrm{X}$ & $\mathrm{T} 2$ \\
\hline
\end{tabular}

\subsection{Subject of the Study}

In doing the research, the researchers choose the subject of this research was the class X Office Administration of SMK St. Familia Tomohon.

\subsection{Research Instrument}

"Research instrument is a tool used for collecting data in a research" (Arikunto, 2006:136). So, the instrument that in collecting the data are in the forms of two test; pre-test and post-test.

Brown (2001:384) states that test is a method of measuring a person's ability of knowledge in a given domain.

In this research, the researchers give an objective test in the form of Matching Test with the total of 20 questions.
The form of the test is combined with the picture based on the technique and the material that used by the writers, for example: Narrative Text.

Then, every question with the right answer got 1 point.

formula:

So, the scoring calculated with

Total score $=\frac{\text { Total points }}{\text { Total questions }} \times 100$

According to Puskur (2006:33), the score can be classified based on the classification of score bellow:

\begin{tabular}{|c|l|l|}
\hline No. & Classification & Score \\
\hline 1. & Very good & $90-100$ \\
\hline 2. & Good & $70-89$ \\
\hline 3. & Fair & $50-69$ \\
\hline 4. & Poor & $30-49$ \\
\hline 5. & Very & $10-29$ \\
\hline
\end{tabular}

\subsection{Data Collection}

In collecting the data, the researchers use the form of Matching Test. There are pre-test and post-test. Pre-test is to find out and to measure the students' achievement without any treatment and post-test is to find out and to measure the students' achievement right after the treatment, and the treatment itself, using Picture and Picture technique.

\subsection{Research Procedure}

Here are the procedures in collecting the data:

- Prepare the instrument for collecting data. 
- Choose the sample class of population

- Prepare the material based on the curriculum that used.

- Give the pre-test to sample class

- Do the treatment, in case the writer does the treatment using "picture and picture" technique.

- Do the post-test to the sample class after applying the "picture and picture" technique to check are the students' reading comprehension can increase after using the technique.

- Compute the data by using the formula and compare the result between the two test; pre-test and post-test to find the conclusion.

- Make a conclusion.

\subsection{Data Analysis}

To analyze the data, the researchers use the mean score formula.

The mean score formula by Hatch and Farhaday (1982:30) is:

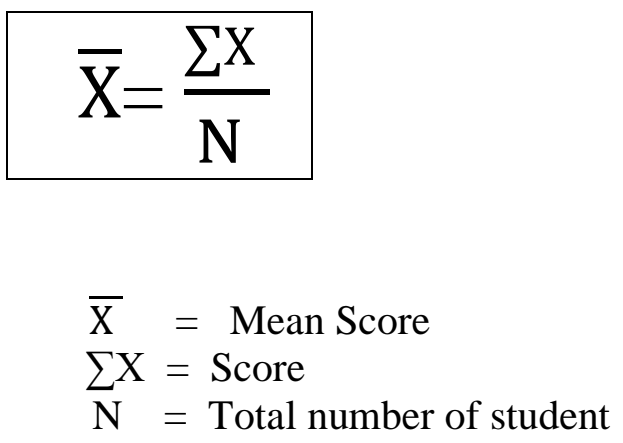

\subsection{Data Analysis and Discussion}

This research is conducted in SMK St. Familia Tomohon of the first grade students. Where one class as the sample is chosen in this research, class $\mathrm{X}$
Office Administration, which consists of 20 students. In collecting the data, the researchers give two kinds of test to the students. The first test is Pre-test and the second test is Post-test. Pre-test that gave to the student is to measure students' ability before the researcher gives any treatment. Meanwhile, Post-test is about to measure students' ability right after the researchers give a treatment.

The researchers give a test in form of objective test with the total of 20 questions.

This chapter consist all the data that have been computed, where all of those are computed in statistically by the researchers.

Here is the following result of Pretest and Post-test in the form of tables based on the collected data:

1. Computing the score of Pre-test (T1)

2. Computing the score of Post-test (T2)

3. Computing Frequency Distribution of Pre-test (T1)

4. Computing Frequency Distribution of Post-Test (T2)

5. Computing the Mean and Standard Deviation (S) of Pre-test (T1)

6. Computing the Mean and Standard Deviation (S) of Post-test (T2)

7. Presenting the scores of Pre-test (T1) and Post-test (T2) in Frequency Polygon.

\subsubsection{Data Analysis}

The table bellow is the scores of PreTest (T1) and Post-Test (T2).

As seen, the higher score of Pre-Test (T1) is 85 and the higher of Post-Test (T2) is 
100. The lowest score of Pre-Test (T1) is 30 and the lowest score of Post-Test (T2) is 80.

Table.1 The scores of Pre-test (T1) and Post Test (T2)

\begin{tabular}{|c|c|c|}
\hline $\begin{array}{l}\text { Students } \\
\text { Number }\end{array}$ & $\begin{array}{c}\text { Pre-test } \\
\text { (test 1) }\end{array}$ & $\begin{array}{c}\text { Post-test } \\
\text { (test 2) }\end{array}$ \\
\hline 1. & 55 & 95 \\
\hline 2. & 60 & 85 \\
\hline 3. & 30 & 100 \\
\hline 4. & 60 & 95 \\
\hline 5. & 55 & 100 \\
\hline 6. & 80 & 95 \\
\hline 7. & 60 & 100 \\
\hline 8. & 55 & 95 \\
\hline 9. & 85 & 100 \\
\hline 10. & 40 & 95 \\
\hline 11. & 40 & 95 \\
\hline 12. & 30 & 90 \\
\hline 13. & 30 & 85 \\
\hline 14. & 30 & 80 \\
\hline 15. & 40 & 90 \\
\hline 16. & 60 & 85 \\
\hline 17. & 60 & 80 \\
\hline 18. & 60 & 90 \\
\hline 19. & 60 & 80 \\
\hline 20. & 60 & 95 \\
\hline
\end{tabular}

Table. 3 Frequency Distribution of Pretest (T1)

\begin{tabular}{|l|l|l|l|l|l|}
\hline Score & Tally & F & F\% & C & CF\% \\
& & & & F & \\
\hline
\end{tabular}

\begin{tabular}{|c|c|c|c|c|c|}
\hline 85 & I & 1 & 5 & 20 & 100 \\
\hline 80 & I & 1 & 5 & 19 & 95 \\
\hline 60 & $\begin{array}{c}\text { IHI } \\
\text { III }\end{array}$ & 8 & 40 & 18 & 90 \\
\hline 55 & III & 3 & 15 & 10 & 50 \\
\hline 40 & III & 3 & 15 & 7 & 35 \\
\hline 30 & IIII & 4 & 20 & 4 & 20 \\
\hline
\end{tabular}

Table. 4 Frequency Distribution of Posttest (T2)

\begin{tabular}{|c|c|c|c|c|c|}
\hline Score & Tally & F & F\% & $\begin{array}{l}\text { C } \\
\text { F }\end{array}$ & CF\% \\
\hline 100 & IIII & 4 & 20 & 20 & 100 \\
\hline 95 & IIII K & 7 & 35 & 16 & 80 \\
\hline 90 & III & 3 & 15 & 9 & 45 \\
\hline 85 & III & 3 & 15 & 6 & 30 \\
\hline 80 & III & 3 & 15 & 3 & 15 \\
\hline
\end{tabular}

Table. 5 The Mean score (x) and Standard Deviation (s) of Pre-test (T1) 


\begin{tabular}{|c|c|c|c|c|}
\hline $\begin{array}{l}\text { Students } \\
\text { Number }\end{array}$ & $\mathbf{X}$ & $\overline{\mathbf{X}}$ & $\mathbf{X}-\overline{\mathbf{X}}$ & $(x-\overline{\mathbf{x}})^{2}$ \\
\hline 1. & 30 & 52.5 & $\begin{array}{l}- \\
22.5\end{array}$ & 506.25 \\
\hline 2. & 30 & 52.5 & $\begin{array}{l}- \\
22.5\end{array}$ & 506.25 \\
\hline 3. & 30 & 52.5 & $\begin{array}{l}- \\
22.5\end{array}$ & 506.25 \\
\hline 4. & 40 & 52.5 & $\begin{array}{l}- \\
12.5\end{array}$ & 156.25 \\
\hline 5. & 60 & 52.5 & 7.5 & 56.25 \\
\hline 6. & 60 & 52.5 & 7.5 & 56.25 \\
\hline 7. & 60 & 52.5 & 7.5 & 56.25 \\
\hline 8. & 60 & 52.5 & 7.5 & 56.25 \\
\hline 9. & 60 & 52.5 & 7.5 & 56.25 \\
\hline 10. & 55 & 52.5 & 2.5 & 6.25 \\
\hline 11. & 60 & 52.5 & 7.5 & 56,25 \\
\hline 12. & 30 & 52.5 & $\begin{array}{l}- \\
22.5\end{array}$ & 506,25 \\
\hline 13. & 60 & 52.5 & 7.5 & 56.5 \\
\hline 14. & 55 & 52.5 & 2.5 & 6.25 \\
\hline 15. & 80 & 52.5 & 27.5 & 756.25 \\
\hline 16. & 60 & 52.5 & 7.5 & 56.25 \\
\hline 17. & 55 & 52.5 & 2.5 & 6.25 \\
\hline 18. & 85 & 52.5 & 32.5 & 1056.25 \\
\hline 19. & 40 & 52.5 & $\begin{array}{l}- \\
12.5\end{array}$ & 156.25 \\
\hline 20. & 40 & 52.5 & $\begin{array}{l}- \\
12.5\end{array}$ & 156.25 \\
\hline & 1050 & & & 4775 \\
\hline
\end{tabular}

$$
\begin{aligned}
& \sum \mathrm{X}=1050 \\
& \mathrm{n}=20 \\
& \overline{\mathrm{X}}=\frac{\sum \mathrm{X}}{\mathrm{n}} \\
& =\frac{1050}{20} \\
& =52.5
\end{aligned}
$$

2. Standard Deviation (s)

$$
\begin{aligned}
s & =\sqrt{\frac{\sum(x-x)^{2}}{\mathrm{n}-1}} \\
s & =\sqrt{\frac{4775}{20-1}} \\
s & =\sqrt{\frac{4775}{19}} \\
s & =\sqrt{251.31} \\
s & =15.85
\end{aligned}
$$

Table.6 The Mean score $(x)$ and Standard Deviation (s) of Post-Test (T2)

\begin{tabular}{|l|c|l|l|c|}
\hline $\begin{array}{l}\text { Students } \\
\text { Number }\end{array}$ & $\mathbf{X}$ & $\overline{\mathbf{X}}$ & $\mathbf{X}-\overline{\mathbf{X}}$ & $(\boldsymbol{X}-\overline{\mathbf{X}})^{2}$ \\
\hline 1. & 90 & 91.5 & -1.5 & 2.25 \\
\hline 2. & 85 & 91.5 & -6.5 & 42.25 \\
\hline 3. & 80 & 91.5 & -11.5 & 132.5 \\
\hline 4. & 90 & 91.5 & -1.5 & 2.25 \\
\hline 5. & 85 & 91.5 & -6.5 & 42.25 \\
\hline 6. & 80 & 91.5 & -11.5 & 132.5 \\
\hline 7. & 90 & 91.5 & -1.5 & 2.25 \\
\hline 8. & 80 & 91.5 & -11.5 & 132.5 \\
\hline 9. & 95 & 91.5 & 3.5 & 12.5 \\
\hline 10. & 95 & 91.5 & 3.5 & 12.5 \\
\hline 11. & 85 & 91.5 & -6.5 & 42.25 \\
\hline 12. & 100 & 91.5 & 8.5 & 72.25 \\
\hline 13. & 95 & 91.5 & 3.5 & 12.5 \\
\hline 14. & 100 & 91.5 & 8.5 & 72.25 \\
\hline 15. & 95 & 91.5 & 3.5 & 12.5 \\
\hline 16. & 100 & 91.5 & 8.5 & 72.25 \\
\hline
\end{tabular}




\begin{tabular}{|l|c|l|l|l|}
\hline 17. & 95 & 91.5 & 3.5 & 12.5 \\
\hline 18. & 100 & 91.5 & 8.5 & 72.25 \\
\hline 19. & 95 & 91.5 & 3.5 & 12.5 \\
\hline 20. & 95 & 91.5 & 3.5 & 12.5 \\
\hline & $\mathbf{1 8 3 0}$ & & & $\mathbf{9 0 5}$ \\
\hline
\end{tabular}

1. Mean score of T2

$$
\overline{\mathrm{X}}=\frac{\sum \mathrm{X}}{\mathrm{n}}
$$

$\overline{\mathrm{X}}=$ Mean Score

$\sum \mathrm{X}=$ Score

$\mathrm{n}=$ Total number of student

$$
\begin{aligned}
\sum X= & 1830 \\
\mathrm{n}= & 20 \\
\overline{\mathrm{X}}= & \frac{\sum \mathrm{X}}{\mathrm{n}} \\
& =\frac{1850}{20} \\
& =91.5
\end{aligned}
$$

2. Standard Deviation

$$
\begin{aligned}
s & =\sqrt{\frac{\sum(x-x)^{2}}{\mathrm{n}-1}} \\
s & =\sqrt{\frac{\sum(x-x)^{2}}{\mathrm{n}-1}} \\
s & =\sqrt{\frac{905}{20-1}} \\
s & =\sqrt{\frac{905}{19}} \\
s & =\sqrt{47.63} \\
s & =6.90
\end{aligned}
$$

Table. 7 Frequency Polygon of Pre-Test (T1) and Post-test (T2)

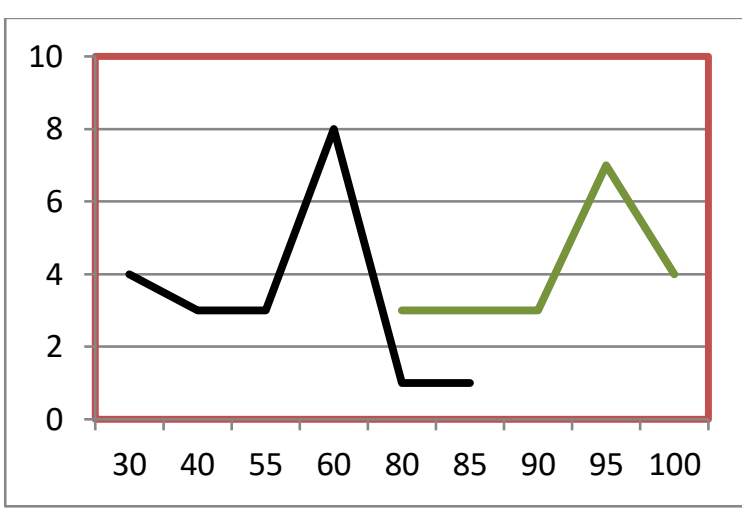

\subsubsection{Interpretation of The Data}

Tables 1 and 2 are about the result of Pre-test (T1) and Post-test (T2). The higher score of Pre-test (T1) is 85 while in Post-test (T2) is 100. The lowest score in Pre-test (T1) is 30 and in Post-test (T2) is 80 . The mean score of Pre-test (T1) is 52.5 and the mean score of Post-test (T2) is 91.5 .

\section{DISCUSSION}

1. The students get so many things such as knowledge, information, idea and message of the written text only by reading. So, that is why reading skill is very important.

2. The technique that used by the researcher, "Picture and Picture" technique is efficient and effective in teaching reading comprehension. This technique also helps the teacher in classroom. The students became more 
active and creative also the classroom situation more interactive.

3. As seen, the score of the students on Post-test were higher than the result of Pre-test. It means that the Picture and Picture technique in Teaching Reading Comprehension is applied effectively, because the grades of the students have increased. So, the Picture and Picture Technique can be used in teaching to improve students reading comprehension.

\section{CONCLUSIONS}

Based on the explanation of the previous chapters, it can be concluded that; first, picture and picture technique is effective to improve students' reading comprehension. The second is teaching reading comprehension by using picture and picture can help student improving their comprehension in reading and increase their cooperation to develop the other language skills.

Then, the last is the result of this research show that the students' score in Post-test is higher than their score in Pretest. It means that Picture and Picture technique in teaching reading comprehension is effective.

\section{SUGGESTIONS}

1. In order to increase students' reading comprehension, it is suggested to apply Picture and picture technique in class related to the situation and material that is going to be taught in school to improve more about students' skill not only in group but also personally.
2. The teacher is suggested to pay more attention to increase students' comprehension in reading.

3. In English teaching, it is important for the teacher to be creative in presenting the material and creating an enjoyable situation in classroom in order to make the student active and enjoy the teaching and learning activity because as know teacher is a facilitator in classroom.

\section{REFERENCES}

Arikunto, Suharsini. 2006. Prosedur Penelitian. Bandung: Rineka Cipta.

Brown, H.D. 2001. Teaching by Principles: (An Interactive Approach to

Language Pedagogy) $2^{\text {nd }}$ ed. New York: Addison Wesley Longman. Inc

Brown. 1980. Principle of Language Learning and Teaching. New York Practice Hall, Inc.

Butler, C. 1985. Statistic in Linguistics. New York: Basil Blackwell.

Istarani. 2011. 58 Model Pembelajaran Inovatif: Referensi Guru dalam Menentukan

Model Pembelejaran. Medan: Penerbit Media Persada.

Kennedy. 1981. Methods in Teaching Development Reading Second Edition. Illnois: Peacock.

Lado, R. 1961. Language Testing: The Construction and Use of Foreign Language Tests: A Teacher's Book. University of Michigan Press. 
Lambe, Livianni. 2011. The Implementation of Learning Together Strategy to Improve the Reading Comprehension Ability of the English Education Department Students of UNIMA. Malang State University.

Lambe, Liviani. 2017. Teaching Reading Comprehension in EFL Classroom: A Glance at Some Approaches and Activities. JELLT, Vol 2.

Liando, Nihta. 2012. Factors Affecting A Successful Language Learner. Publication Article. Indonesian JELT. Vol 8. No 1. 89.

http://ojs.atmajaya.ac.id/index.php/ije $\underline{1 t / a r t i c l e / v i e w / 89}$

Liando, Nihta \& Lumenttu, Raesita. 2017. Student' Personal Initiative towards their Speaking Performance. International Education Studies. Vol. 10. Number 8. P. 21 http://www.ccsenet.org/journal/index/ php/ies/article/view.65175

Liando, Nihta. 2010. Students' Vs. Teachers' Perspectives on Best Teacher Characteristics in EFL Classrooms. TEFLIN Journal. Vol. 21. Number 2. P.

118.

http://journal.teflin.org/index.php/jour nal/article/view/37

Liando, Nihta. 2009. Students' Perspectives on Motivation to Learn English. Celt. Vol. 9. Number 2. P. 151. http://journal.unika.ac.id/index.php/ce lt/article/view/169

Liando, Nihta. 2012. Factors affecting a successful language learner.
Indonesian Journal of English Language Teaching Vol. 8, No. 1.

Maru, Mister Gidion. 2009. Engaging Literary Text to Language Exposure for foreign English Learners. International Conference on TELF/ICOTEFL. Muhamadiyah University Purwekerto, Indonesia. https://www.academia.edu/22524149/ Engaging

_Literary_Text_to_Language_Exposu re_for_Foreign_English_Learners.

McMillan H. \& S. Schumacher. 1984. Research in Education. A Conceptual Introduction. Boston.

Puskur. 2006. Metode Penelitian Pendidikan. Yogyakarta: PT Gava Media.

Richard, J.C \& Th.S. Rodgers. 1986.

Approaches and Methods in Language Teaching. Cambridge University Press.

Smith, Robinson. 1980. Efficient Reading, A Partial Guide to Reading Comprehension on Exercise. New York: Cambridge University Press.

The New International Webster's Comprehensive Dictionary of English Language. 1996. Florida: Trident Press International. 